\title{
REFERENCES
}

Allfrey, V., Stern, H. \& Mirsky, A. E. (1952). Nature, Lond., 169, I28.

Folley, S. J. \& Watson, S. C. (1948). Biochem. F. 42, 204.

Goldner, J. (1938). Amer. F. Path. 14, 237.

Harrison, M. F. \& Brown, L. M. (1951). Biochem. F. 48, 15 I.

Kahane, E. \& Lévy, J. (1936). Bull. Soc. Chim. biol., Paris, 18, 529.

McCance, R. A., Brown, L. M., Comline, R. S. \& Titchen, D. A. (195 I). Nature, Lond., r68, 788.

McCance, R. A., Hutchinson, A. O., Dean, R. F. A. \& Jones, P. E. H. (1949). Biochem. F. 45, 493.

Mason, J. H., Dalling, T. \& Gordon, W. S. (1930). F. Path. Bact. 33, 783.

Schneider, L. \& Szathmáry, J. (1939). Z. ImmunForsch. 95, 177.

\section{A Radiological Study of the Rate of Passage of Brown and White Bread through the Digestive Tract of Man}

\author{
By R. A. MCCANCE, KATHLEEN M. PRIOR AND ELSIE M. WIDDOWSON \\ Medical Research Council Department of Experimental Medicine, \\ University of Cambridge
}

(Received 6 March 1952)

\begin{abstract}
'Breadde havynge moche branne fylleth the bealye with excrementes and... shortely descendeth from the stomacke' (Elyot, I54I). 'I have known this experience of it, that such as have been costive, by eating browne bread and butter have been made soluble' (Cogan, I 588). 'These effects of wholemeal bread upon the bulk and passage of the faeces, which were common knowledge in the sixteenth century, had been described over I 500 years earlier by Galen and Hippocrates, and all the scientific work that has been carried out in the last 100 years has confirmed them. Increasing the extraction rate of the flour introduces celluloses and hemicelluloses into the diet. These carbohydrates, being fibrous and only incompletely digested and absorbed, increase the calorific value of the faeces. Raising the extraction rate, however, also decreases the 'apparent' digestibility of many of the other constituents of flour (Meyer, I871; Rubner, I883, I9I7; Snyder, I905, I908; Newman, Robinson, Halnan \& Neville, I9r2; McCance \& Walsham, I948-9). The greater amount of nitrogen in the faeces on a brown bread diet was at one time thought to be due to the protein. of the branny fractions not being well digested and absorbed, but from the work of Borgström (r94I), McCance \& Widdowson (1947) and McCance \& Walsham (1948-9) it now seems probable that in man at any rate it is due rather to an increased amount of digestive secretions called forth by the nature of the diet. The digestibility of the fat in wholemeal bread, however, is also very low (McCance \& Walsham, 1948-9), about $40 \%$ of the intake being excreted in the faeces, and since it is unlikely that the digestive juices contain fat, the reason in this instance may be that the lipolytic enzymes do not penetrate freely into the cells of the bran and germ. So far as the inorganic constituents of wheat are concerned, the presence of a large part of the phosphorus in wholemeal in the form of phytates is probably the most important
\end{abstract}


reason for the poorer absorption of calcium, magnesium and phosphorus from brown bread diets (McCance \& Widdowson, 1942-3). Potassium (McCance \& Widdowson, I942-3), lithium and other minor elements (Kent \& McCance, I94 $a, b$ ) are also less completely absorbed from brown than from white bread diets, but whether these ions are retained in the gut by mechanical 'indigestibility' or to maintain osmotic equilibrium is not yet known.

It is well known that 'markers' such as carmine pass along the whole length of the digestive tract more rapidly if a person is eating brown bread than if he is eating white, but there is still no scientific evidence as to where the speed-up takes place. Does a meal of brown bread leave the stomach more rapidly than one of white as suggested by Elyot in the picturesque language and spelling of the sixteenth century? If both breads pass along the small gut at the same rate, it is unlikely that the poorer absorption from brown bread can be related to the rate of passage through the gut. If, on the other hand, the difference in the rate of passage applies to the small gut as well as to the large intestine, it is possible that this may help to explain the poorer absorption from brown bread. It was decided, therefore, to investigate radiologically the effect of bread made from flours of two different extractions on the transit times of barium sulphate through the alimentary tracts of normal persons by giving a small quantity of barium sulphate mixed with a large amount of bread. Such a method is not new, for in the early days of radiology the alimentary tract was examined by mixing bismuth salts with food (Rieder, I904; Hertz, 1907; Groedel, 1908, 1910; Holzknecht, I9II-I2; Knox; I9II-12; Cole, I9I I-12; Haudek, 19II-I2) and later barium sulphate with food (Günther, 19II-I2; Case, I912; Barclay, 1912-13; Hertz, I9I 2-I3; Groedel, I912-I3). Cole (19I4) stated that the true test of gastrointestinal 'motor-efficiency' was made by giving a suspension of barium sulphate mixed with a meal of meat, potatoes and bread. The quantities of barium sulphate which these early workers used was considerable, so that the alimentary tract was clearly outlined. In this investigation it was decided to use as little barium sulphate as possible so that it would cause a minimal effect on the passage of the meal through the gut.

\section{EXPERIMENTAL}

The subjects. Six subjects, three men and three women, whose ages ranged from 25 to 35 years, took part in this experiment. For each of them there were two experimental periods, in one of which the diet consisted largely of brown bread and in the other of white bread. Four of the subjects had brown bread during their first period and white during the second, while the other two started on white bread and finished with brown. The interval between the two periods varied from I to 7 weeks.

The breads. The flours used for baking the breads for these experiments were milled at the Cereals Research Station, St Albans, under the direction of Dr T. Moran. They were of two extractions, 100\% (brown) and $70 \%$ (white). They were not treated with any improver or bleaching agent, and they did not contain added calcium carbonate. The flour of $100 \%$ extraction contained $\mathrm{I} \cdot 82 \%$ fibre; the amount in the 
white flour was negligible. Bread was baked from the experimental flours at a small bakery and was made with yeast in the ordinary way.

The diets. About three-quarters of the total daily calories was provided by one or other of the experimental breads. Of white bread $5 \%$ less by weight than of brown bread was eaten to allow for the different amounts of moisture in the two breads. The other foodstuffs that were eaten contained no roughage, and they were chosen so that they could easily be obtained again in the second period. Small amounts of eggs, cheese, bacon, meat, butter, bramble jelly and golden syrup were allowed, each subject choosing his own foods. During the second period the meals of each subject were identical with the corresponding meals of the same subject in the first period.

Experimental procedure. For 2 days the subjects ate the experimental diet containing one or other of the breads. On the 3 rd day they had their usual experimental breakfast and nothing further for $5 \mathrm{~h}$. Then they ate the test meal. This consisted of $300 \mathrm{~g}$ brown bread or $285 \mathrm{~g}$ white bread, spread with a paste consisting of $15 \mathrm{~g}$ barium sulphate mixed with three teaspoonfuls of water. Four of the subjects drank $200 \mathrm{ml}$. water with the meal, and the other two, B.S. and R.H., I 35 and I $15 \mathrm{ml}$., respectively. Three capsules, each containing about $0.25 \mathrm{~g}$ carmine, were swallowed at the beginning of the meal to indicate when the residue of this particular meal first appeared in the faeces.

As soon as the subjects had finished eating the test meal, they cycled about half a mile to the X-ray Department where the radiological investigations were carried out. The examinations began about a quarter of an hour after the end of the test meal. The subjects were screened or radiographs were taken every half hour or so for the following $8 \mathrm{~h}$. They did not eat or drink anything more until $6 \mathrm{~h}$ after the test meal, or even longer if the stomach had not evacuated the meal by this time. The further progress of the meal through the alimentary tract was studied by examining the subjects radiologically every day until all the barium sulphate had been evacuated from the gut. They continued to eat the experimental diet during this time.

\section{RESULTS}

On the whole, but particularly at first, the subjects preferred the diet of white bread. The brown bread required more chewing and took longer to eat. One or two felt some indigestion while they were eating the brown bread. They found, however, as the days progressed they got to like the brown bread more and the white bread less.

Eating a meal of bread is a lengthy procedure (McCance \& Widdowson, 1946), and the number of minutes taken to eat the test meals of brown and white bread is given in Table I. Reckoning from the middle of the time taken to eat the meal, the times taken for the stomach to empty (the gastric emptying time) and for the head of the meal to reach the caecum (the small-intestinal transit time) were calculated to the nearest half-hour.

The barium sulphate appeared to be more evenly distributed amongst the gastric contents after the meal of brown bread than after the meal of white bread (Pl. I, I). In most of the subjects the shadow of the stomach appeared larger after the brown bread meal, but this was not so evident in subject L.T. After both meals a little 
Table I. The passage of test meals of brown and white bread through the alimentary tracts of six human subjects

\begin{tabular}{|c|c|c|c|c|c|c|c|c|c|}
\hline \multirow[b]{2}{*}{ Subject } & \multirow[b]{2}{*}{ Sex } & \multicolumn{2}{|c|}{$\begin{array}{c}\text { Time taken to eat } \\
\text { test meal }\end{array}$} & \multicolumn{2}{|c|}{$\begin{array}{c}\text { Gastric emptying } \\
\text { time* }\end{array}$} & \multicolumn{2}{|c|}{$\begin{array}{l}\text { Small-intestinal } \\
\text { transit time* }\end{array}$} & \multicolumn{2}{|c|}{$\begin{array}{c}\text { Total excretion } \\
\text { of test meal }\end{array}$} \\
\hline & & $\begin{array}{c}\text { Brown } \\
\text { (min) }\end{array}$ & $\begin{array}{l}\text { White } \\
\text { (min) }\end{array}$ & $\begin{array}{l}\text { Brown } \\
\text { (h) }\end{array}$ & $\begin{array}{l}\text { White } \\
\text { (h) }\end{array}$ & $\begin{array}{l}\text { Brown } \\
\text { (h) }\end{array}$ & $\begin{array}{l}\text { White } \\
\text { (h) }\end{array}$ & $\begin{array}{l}\text { Brown } \\
\text { (days) }\end{array}$ & $\begin{array}{l}\text { White } \\
\text { (days) }\end{array}$ \\
\hline I.H. & $\mathbf{M}$ & 46 & 40 & $3 \cdot 5$ & 5 & $3 \cdot 5$ & $4 \cdot 5$ & 2 & 3 \\
\hline B.S. & $\mathbf{M}$ & 45 & $3 \mathrm{I}$ & $5 \cdot 5$ & 7 & $4 \cdot 5$ & 6.5 & 2 & 3 \\
\hline R.H. & $\mathbf{M}$ & 56 & 41 & 3 & 3.5 & $6 \cdot 5$ & $6 \cdot 5$ & 2 & 3 \\
\hline L.T. & $\mathrm{F}$ & 35 & 25 & 4 & 5 & 3 & 6 & 2 & 3 \\
\hline B.P. & $\mathrm{F}$ & 42 & 26 & 5 & 6 & 3 & $4 \cdot 5$ & 2 & 3 \\
\hline K.P. & $F$ & 45 & 40 & 4 & 5 & 6 & 7 & 3 & 4 \\
\hline
\end{tabular}

barium sulphate gravitated to the bottom of the stomach when the subjects stood up. By the time the first radiographs were taken, about $\mathrm{I} h$ after the middle of the test meal, some of both meals had already passed into the jejunum. In the small intestine the barium appeared to be homogeneously mixed with both breads. In the jejunum it produced only a faint shadow, but with both meals the shadow of the barium became more opaque as the meals passed down the gut (P1. I, 2). In the lower jejunum and ileum the column of barium appeared more opaque and the calibre of the gut narrower with the white bread meal than with the brown (PI. I, 3). The mucosal folds were visualized with both the bread meals and there was no evidence of flocculation of the barium sulphate.

The gastric emptying times and the small-intestinal transit times for the test meals of brown and white bread are given in Table $I$. The brown bread meal left the stomach more quickly than the white, the difference between the two gastric emptying times varying from 0.5 to $\mathrm{I} .5 \mathrm{~h}$ and averaging $\mathrm{I} h(t=7 . \mathrm{I}, P=<0.0 \mathrm{I})$. The head of the white bread meal also took longer to reach the caecum. In one subject, R.H., no difference was observed between the transit times for the brown and for the white bread, but for all the other subjects differences of $\mathrm{I}-3 \mathrm{~h}$ were found. The average 'delay' in the small intestinal transit time for the white bread meal for the six persons was $\mathrm{I} \cdot 5 \mathrm{~h}(t=3.4, P=0.02-0.0 \mathrm{I})$.

There was still some residue left in the terminal ileum of all the subjects $7 \mathrm{~h}$ after both test meals, but there was more after eating the white bread than the brown (Pl. 2, I). In one subject, I.H., the small intestine was almost clear of both meals in $8 \mathrm{~h}$; the residue of the brown meal was entirely in the large bowel at this time but a few flecks of barium from the meal of white bread were still in the ileum.

Barium sulphate could be seen from the ascending colon to the rectum in all the subjects $20 \mathrm{~h}$ after the meal of brown bread. After the meal of white bread the barium was distributed throughout the colon $20 \mathrm{~h}$ later in five persons; in the sixth person it was spread only from the caecum to the splenic flexure. The residue from the brown bread was more homogeneous, and the colon was wider when it contained the residue from the brown bread than when it contained the residue from the white bread (P1. 2, 2). By the 2nd morning after the test meal of brown bread the barium 
sulphate had been evacuated from the colon and rectum in five of the six people. The colon of the sixth person was not clear of the barium until the $3^{\text {rd morning. On }}$ the and morning after the test meal of white bread the barium sulphate was still visible in the colon from the caecum to the rectum in all the subjects (Pl. 2, 3). On the $3^{\text {rd }}$ morning four people had evacuated it all, but two subjects still had some barium sulphate left in the colon.

Two of the subjects excreted carmine 9 and $9.5 \mathrm{~h}$ after eating the meal of brown bread. Three others excreted carmine the following morning, but the sixth person did not excrete the carmine until I day later. In every subject the carmine took longer to appear after the white bread meal than it did after the brown, the difference varying from $6 \mathrm{~h}$ to 2 days. It is probable that the barium sulphate and the carmine remained mixed in the colon, because barium sulphate was observed radiographically in the rectum at about the time that the carmine was first excreted, and the carmine continued to colour the faeces until the barium sulphate had been evacuated from the colon.

\section{DISCUSSION}

Stomach. The greater area of opacity after the brown bread meal could not have been due to a difference in the size of the meals. It suggests that the 'brown' meal called forth a larger amount of secretion, and this has, in fact, been observed before (Nefedov, 1940). Whether this secretion is salivary or gastric is not yet known, but the former would appear to account at any rate for part of the difference, for the brown bread required more chewing and took longer to eat. Better chewing may also explain the more even distribution of barium throughout the stomach contents of most of the subjects after the brown bread meal, for in I.H., who took particular care to chew the white bread as much as he had done the brown, the barium sulphate was fairly well mixed with both the breads. There is some evidence that it takes longer for a large meal to leave the stomach than for a small one (Van Liere, Sleeth \& Northup, 1937), yet here, judging from the size of the secretions and meal taken together, the reverse was true. Lower viscosity may have helped the expulsion of the brown meal. Whatever the reason, Elyot's intuition allowed him to anticipate the observation by 400 years.

Small intestine. If an increase in opacity towards the lower end of the small gut be taken to indicate concentration of barium following the absorption of the meals, then the greater opacity in the lower jejunum and the narrower calibre of these portions of the gut after the white meal suggests that its absorption had been more rapid and complete. It is the 'filling' effect of the hydrated celluloses and hemicelluloses rather than their mechanical irritation that probably accounts for the more rapid transit of the brown bread through the small gut. The 'delay' in the rate of passage of the white bread meal through the small intestine will not, of course, account for the whole of the 'delay' in the time of appearance of the carmine because food residue normally takes many times longer to pass through the large than through the small gut. Proportionally, the 'delay' was almost as great in the small as in the large intestine, and it is possible that this is responsible for some of the difference in the apparent digestibilities of the two breads. 
The gastric and intestinal secretions appeared to cause no flocculation of the barium sulphate. This may have been due to the protective effect of the colloids contained in bread, for Zimmer (195I) has shown that in the presence of colloids barium sulphate is not flocculated by the secretions from the small gut.

The large gut. As in the stomach and small intestine there is radiological evidence that the large gut had more in it after the brown bread meal than after the white. The bulk of the faeces confirmed this and it is suggested that greater bulk, together with greater malleability, were the main reasons for the more rapid transit and expulsion of the brown bread residues.

\section{SUMMARY}

I. The passage of brown and white bread through the alimentary tracts of six healthy men and women was studied radiologically by the addition of a small quantity of barium sulphate to the bread.

2. The brown bread appeared to stimulate a greater secretion of saliva or of gastric juice or of both than did the white bread.

3. The brown bread was evacuated from the stomach and passed through the small intestine more rapidly than the white bread.

4. The residue from the brown bread, when in the ileum and in the colon, appeared to be greater than that from the white bread.

5. The residue from the brown bread left the colon $24 \mathrm{~h}$ sooner than that from the white bread.

The authors are very grateful to $\mathrm{Dr} F$. R. Berridge for permitting the X-ray examinations to be carried out on his apparatus, and for his help in interpreting the findings; they are also indebted to the subjects for allowing their digestive tracts to be used for these experiments.

\section{REFERENCES}

Barclay, A. E. (1912-13). Arch. Roentg. Ray, r7, 327.

Borgström, S. (1941). Acta physiol. scand. 2, Suppl. 7.

Case, J. T. (1912). Proc. R. Soc. Med. 5, part 1, Electrotherapeutical Section, p. 73.

Cogan, T. (1 588). The Haven of Health, or The Art of Prolonging Life by the Force of Physicke. London: Thomas Creede.

Cole, L. G. (I911-12). Arch. Roentg. Ray, 16, 242.

Cole, L. G. (1914). Amer. F. med. Sci. 148, 92.

Elyot, T. (1541). The Castel of Helth, Corrected and in Some Places Augmented. The Seconde Boke, Cap. ri, Of Breade, p. 28. London: Th. Berthelet.

Groedel, F. M. (1908). Berl. klin. Wschr. 45, 742.

Groedel, F. M. (1910). Dtsch. med. Wschr. 36, 701.

Groedel, F. M. (1912-13). Arch. Roentg. Ray, 17; 420.

Günther, H. (191 1-12). Arch. Roentg. Ray, 16, 45.

Haudek, M. (191 I-12). Arch. Roentg. Ray, 16, 6.

Hertz, A. F. (1907). Guy's Hosp. Rep. 6r, 389.

Hertz, A. F. (19г2-г3). Arch. Roentg. Ray, 17, 216.

Holzknecht, G. (1911-12). Arch. Roentg. Ray, 16, 206.

Kent, N. L. \& McCance, R. A. (1941 $a$ ). Biochem. F. 35, 837.

Kent, N. L. \& McCance, R. A. (1941 b). Biochem. F. 35, 877.

Knox, R. (191 1-12). Arch. Roentg. Ray, 16, 283.

McCance, R. A. \& Walsham, C. M. (1948-9). Brit. F. Nutr. 2, 26.

McCance, R. A. \& Widdowson, E. M. (1942-3). F. Physiol. Ior, 44. 
McCance, R. A. \& Widdowson, E. M. (1946). Spec. Rep. Ser. med. Res. Coun., Lond., no. 254.

McCance, R. A. \& Widdowson, E. M. (1947). F. Hyg., Camb., 45, 59.

Meyer, G. (1871). Z. Biol. 7, 1 .

Nefedov, I. I. (1940). Problems of Nutrition, Moscow, 9, no. 5, p. 13, from Nutr. Abstr. Rev. (1942-3), 12, 237.

Newman, L. F., Robinson, G. W., Halnan, E. T. \& Neville, H. A. D. (1912). F. Hyg., Camb., I2, 119. Rieder, H. (1904). Münch. med. Wschr. 51, 1548.

Rubner, M. (1883). Z. Biol. I9 (N.F.), I, 45 .

Rubner, M. (1917). Arch. Anat. Physiol., Lpz. (Physiol. Abt.), p. 255.

Snyder, H. (1905). Bull. U.S. Off. Exp. Stas. no. 156.

Snyder, H. (1908). Human Foods and their Nutritive Value. New York: The Macmillan Co.

Van Liere, E. J., Sleeth, C. K. \& Northup, D. (1937). Amer. F. Physiol. 119, 480.

Zimmer, E. A. (1951). Brit. F. Radiol. 24, 245.

\section{EXPLANATION OF PLATES}

Subject L.T.

Plate I

I. $58 \mathrm{~min}$. Supine. In the stomach the barium sulphate was better mixed with the brown bread (a) than with the white bread $(b)$.

2. $2 \mathrm{~h} 23 \mathrm{~min}$. Prone. At this time the gastric residue was larger after the white (b) than after the brown $(a)$ bread meal. The muscosal folds of the jejunum could just be visualized with both meals.

3. $3 \mathrm{~h} 16 \mathrm{~min}$. Supine. The calibre of the ileum was narrower and the concentration of barium sulphate greater with the white bread meal $(b)$. The barium sulphate had just reached the caecum in the brown bread experiment $(a)$.

\section{Plate 2}

I. $6 \mathrm{~h} 36 \mathrm{~min}$. Supine. Most of the barium sulphate taken with the white bread $(b)$ still remained in the ileum whereas most of that taken with the brown bread (a) had passed into the large bowel.

2. 2I h. Prone. The appearance of the barium sulphate was more homogeneous and the calibre of the colon wider when it contained the residue of the brown bread meal $(a)$.

3. 44 h. Prone. The brown bread meal $(a)$ had been completely evacuated from the colon. There was still a considerable residue from the white bread meal $(b)$. 
R. A. McCANCE, KATHLEEN M. PRIOR \& ELSIE M. WIDdOWSON. Plate I BROWN AND WHITE BREAD IN THE GUT
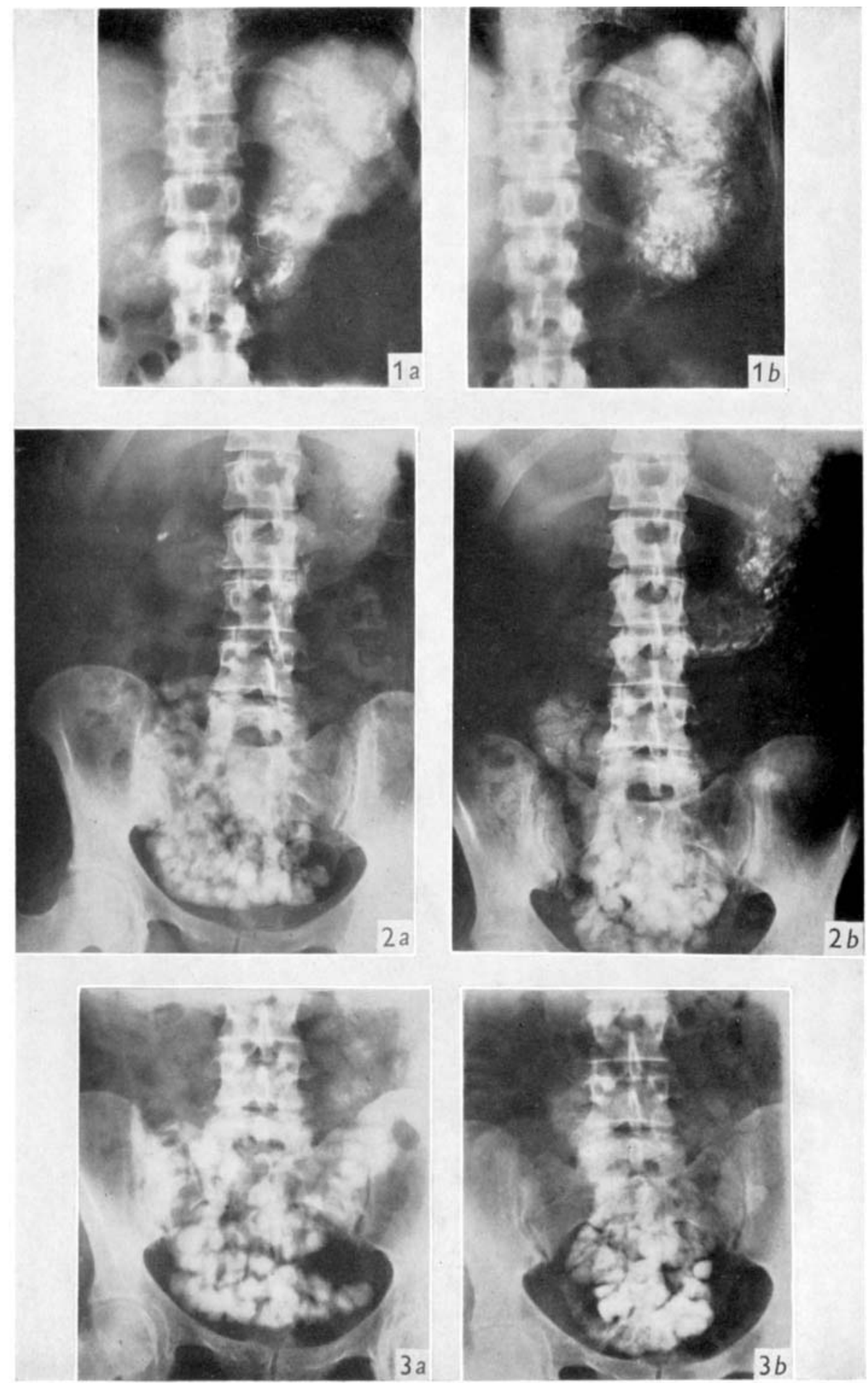

British Fournal of Nutrition, Vol. 7 , Nos. I $\xi_{2}$ 
R. A. McCANCE, KATHLEen M. PRIOR \& ELSIE M. WIDdOWSON. Plate 2 BROWN AND WHITE BREAD IN THE GUT
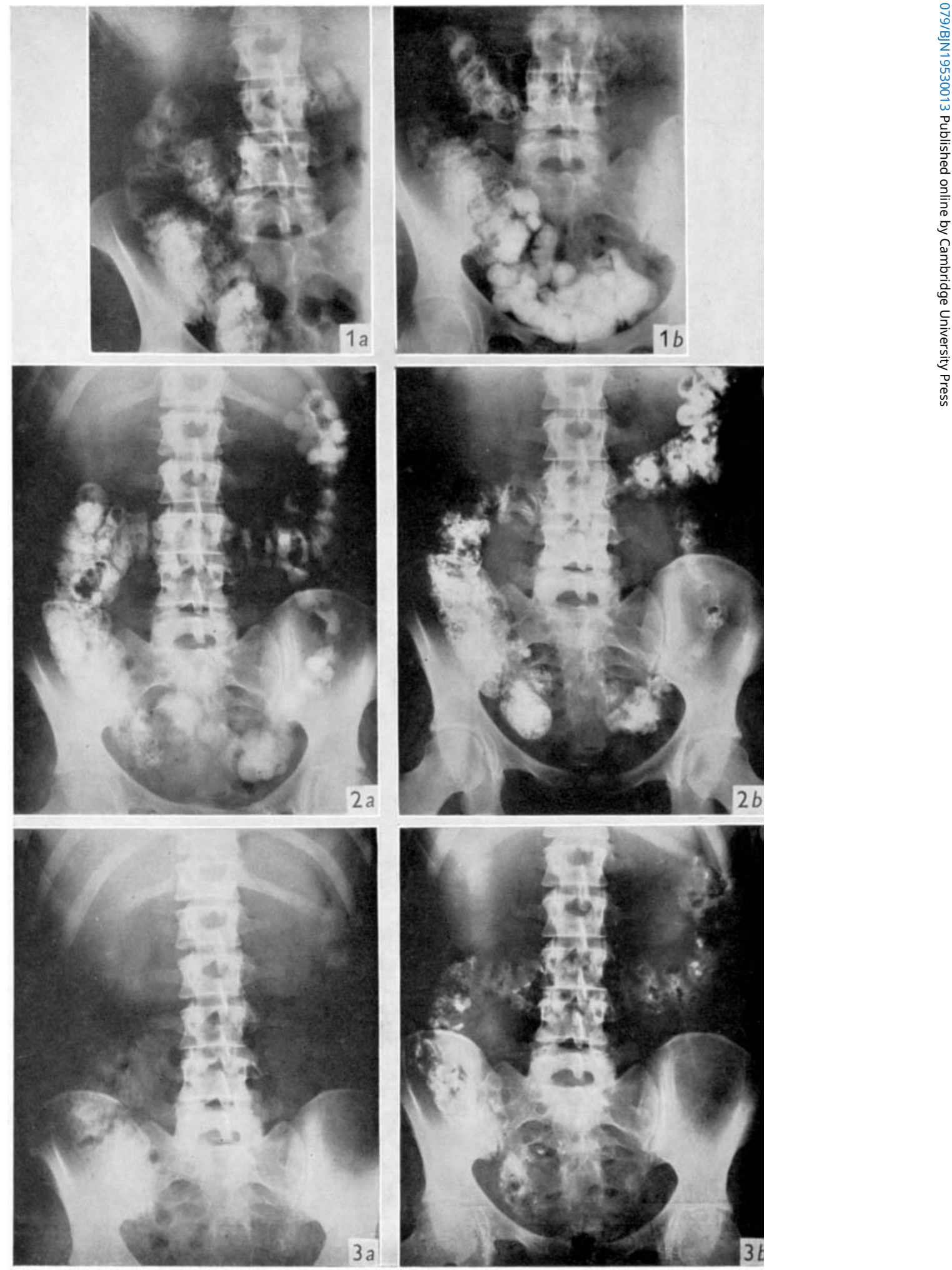

British fournal of Nutrition, Vol. 7, Nos. I $\mathscr{F}_{2}$ 